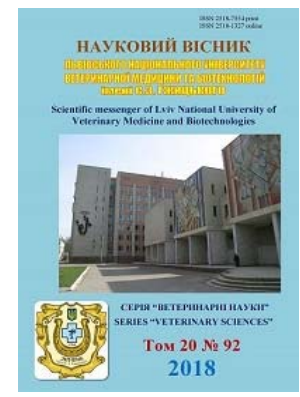

\author{
Науковий вісник Дьвівського національного університету \\ ветеринарної медицини та біотехнологій імені С.З. Гжицького
}

\author{
Scientific Messenger of Lviv National University \\ of Veterinary Medicine and Biotechnologies
}

UDC 619:615.451.3:618.14.089

\title{
Investigation of stability of intrauterine aerosol preparation "Yodozol"
}

\author{
R.M. Sachuk ${ }^{1}$, O.A. Katsaraba ${ }^{2}$ \\ ${ }^{1}$ Research Epizootology Station IVM NAAS, Rivne, Ukraine \\ ${ }^{2}$ Stepan Gzhytskyi National University of Veterinary Medicine and Biotechnologies Lviv, Ukraine
}

Article info

Received 10.10.2018

Received in revised form 12.11.2018

Accepted 13.11.2018

Research Epizootology Station IVM NAAS, Knyaz Vladimir Str., 16/18,

33028, Rivne, Ukraine.

Tel.: +38-097-671-90-63

E-mail: sachuk.08@ukr.net

Stepan Gzhytskyi National University of Veterinary Medicine and Biotechnologies Lviv,

Pekarska Str., 50, Lviv,

79010, Ukraine.

Tel.: +38-067-670-68-46

E-mail: Katsaraba@gmail.com
Sachuk, R.M., \& Katsaraba, O.A. (2018). Investigation of stability of intrauterine aerosol preparation "Yodozol". Scientific Messenger of Lviv National University of Veterinary Medicine and Biotechnologies, 20(92), 29-33. doi: 10.32718/nvlvet9206

For standardization, quality control, study of stability and establishment of storage conditions and terms of use, complex preclinical trials of the new development of PE "Biopharm" and the Experimental Station of Epizootology IVM NAAN - aerosol preparation "Yodozol" have been carried out. The methods of evaluation of a medicinal product applied to aerosols are used, which include: determination of changes in appearance, inspection of packaging for leakproofness, measurement of the percentage of contents of the package, the establishment of qualitative and quantitative indicators of active substances, and also the study of microbiological purity of the product. "Yodozol" is a light yellow liquid, $1 \mathrm{ml}$ of which contains $5 \mathrm{mg}$ of iodine and $10 \mathrm{mg}$ of potassium iodide. The drug is used for the prevention and treatment of postnatal intrauterine infections in cows, pigs, sheep and goats (endometritis, pyrometers, cervicitis, vaginitis, delayed digestion caused by microorganisms sensitive to iodine), after obstetrics aid, cesarean section and postpartum sanitation of the uterus. The drug has antimicrobial, anti-inflammatory and analgesic effects, improves the proliferative processes of the genital organs, reduces the time for recovery of animals. The drug is used according to the guidelines, after its production livestock is used without restrictions. The shelf-life, which is the result of the test of the dasg according to the «stability» indicator, has been determined, which was performed under long-term storage in a place protected from light at a temperature range from $+5 \pm 2{ }^{\circ} \mathrm{C}$ to $+25 \pm 2{ }^{\circ} \mathrm{C}$. The studies conducted after 6,12, 24 and 30 months showed complete compliance of the quality indices with the declared standards when stored for 24 months in the temperature corridor from $+5{ }^{\circ} \mathrm{C}$ to $+20^{\circ} \mathrm{C}$. With an increase in storage temperature to $+25^{\circ} \mathrm{C}$ or more, a slight quantitative decrease in the concentration of antimicrobial components occurred. In addition, with long-term storage of drugs, release of the contents from the cylinder became uneven and foam acquired a shade less than the saturation rate, increased microbiological contamination. Thus, according to the results of the study, the established shelf life of the preparation is 2 years at the recommended storage temperature from +5 to $+20^{\circ} \mathrm{C}$. All studies conducted on the stability of the aerosol intrauterine drug "Yodozol" were included in the registration materials of the medicinal product.

Key words: iodine, potassium iodide, content, identity, stability, shelf life, "Yodozol".

\section{Дослідження стабільності внутрішньоматкового аерозольного препарату “Йодозол"}

\author{
Р.М. Сачук ${ }^{1}$, О.А. Кацараба ${ }^{2}$ \\ ${ }^{1}$ Дослідна станиія епізоотологї ІВМ НААН, м. Рівне, Украӥна \\ ${ }^{2}$ Львівський національний університет ветеринарної медиџини та біотехнологій імені. С.3. Гжицького, \\ м. Львів, Украӥна
}

\footnotetext{
Для стандартизачії, контролю якості, вивчення стабільності та встановлення умов зберігання і термінів використання, проведено комплексні доклінічні випробування нової розробки ПП “Біофарм” та Дослідної станиї епізоотологї ІВМ НААН - аерозольного препарату “Йодозол”. Використані методи оцінки лікарського засобу, щчодо аерозолів, які включають: визначення змін зовнішнього вигляду, перевірку упаковки на герметичність, вимірювання відсотка виходу вмісту з упаковки, встановлення якісних та кількісних показників діючих речовин, а також дослідження мікробіологічної чистоти засобу. “Йодозол” - спінена рідина світло-жсовтого кольору, 1 мл якої містить 5 мг йоду та 10 мг калію йодиду. Препарат застосовують для профілактики та ліку-
} 
вання післяродових внутрішньоматкових інфекцій у корів, свиней, овець $і$ кіз (ендометритів, пірометри, изервіцитів, вагінітів, затримки посліду, спричинених чутливими до йоду мікроорганізмами), після надання рододопомоги, кесаревого розтину та післяродової санації матки. Лікарський засіб володіє протимікробною, протизапальною та знеболювальною діями, поліпиує проліферативні прочеси статевих органів, скорочує терміни одужання тварин. Препарат застосовують згідно з настановою, після чого продукиію тваринництва використовують без обмежень. Визначено термін придатності, шо є результатом випробувань препарату за показником “стабільність”, проведених за умови довготривалого зберігання у захищеному від світла місиі при діапазоні температур від $+5 \pm 2{ }^{\circ} \mathrm{C}$ до $+25 \pm 2{ }^{\circ} \mathrm{C}$. Дослідження, проведені через 6, 12, 24 та 30 місячів показали повну відповідність показників якості заявленим нормам при зберіганні впродовж 24 місяців у температурному коридорі від $+5{ }^{\circ} \mathrm{C}$ до $+20{ }^{\circ} \mathrm{C}$. При підвищенні температури зберігання до $+25{ }^{\circ} \mathrm{C}$ і більще, відбувалося незначне кількісне зниження концентрації антимікробних компонентів. Окрім того, при довготривалому зберіганні препаратів випуск вмісту з балона ставав нерівномірним і піна набувала відтінку меншого за норму насиченості, збільшувалась мікробіологічна контамінація. Таким чином, відповідно до результатів дослідження встановлений допустимий термін придатності препарату складає 2 роки при рекомендованій температурі зберігання від +5 до $+20{ }^{\circ}$ C. Усі проведені дослідження стабільності аерозольного внутрішньоматкового препарату “Йодозол” увійшли до реєстраиійних матеріалів лікарського засобу.

Ключові слова: йод, калію йодид, вміст, ідентичність, стабільність, термін придатності, “Йодозол”.

\section{Ветуп}

Для профілактики і лікування післяродових внутрішньоматкових інфекцій у корів, кобил, свиней, овець і кіз ПП “Біофарм” спільно з Дослідною станцією епізоотології IBM НАAН розроблено новий аерозольний внутрішньоматковий препарат “Йодозол”, до складу якого входить йод та калію йодид. Обов'язковою умовою реєстрації нових лікарських препаратів є дослідження їх стабільності при зберіганні. Вивчення придатності лікарських препаратів 3 метою отримання інформації про зміну їхньої якості з часом і під впливом факторів навколишнього середовища (температури, вологості, освітлення тощо) є обов'язковим видом фармацевтичних досліджень (Kotsyumbas et al., 2006).

Також потрібно врахувати, що вивчення стабільності лікарських засобів $є$ одним 3 чільних питань системи забезпечення якості. Відповідно до законодавства розвинених країн світу, правил Належної виробничої практики одним з обов'язків розробника $\epsilon$ дослідження стабільності, які необхідно здійснювати і на етапі розроблення активної речовини, і лікарського препарату (Heorhiievskyi et al., 2004; Gutyj et al., 2016; Todoriuk et al., 2018; Gutyj et al., 2018).

Метою роботи було встановлення максимального терміну придатності та вивчення показників стабільності аерозольного внутрішньоматкового препарату “Йодозол” при зберіганні у металевому контейнері (балоні), який закривають та герметизують клапаном.

\section{Матеріали і методи досліджень}

В роботі використано нову розробку - аерозольний внутрішньоматковий препарат “Йодозол”, до складу якого входить йод, у кількості 5 мг в 1 мл препарату та калію йодид - 10 мг, відповідно. Піноутворюючий аерозоль застосовують для профілактики та лікування післяродових внутрішньоматкових інфекцій у корів, свиней, овець і кіз (ендометритів, пірометри, цервіцитів, вагінітів, затримки посліду, спричинених чутливими до йоду мікроорганізмами) після надання рододопомоги, кесаревого розтину та післяродової санації матки. За умови застосування препарату згідно з листівкою-вкладкою продукцію тваринництва використовують без обмежень. Препарат розфасований у металеві контейнери (балони) - місткіс- тю $60 \mathrm{~cm}^{3}$, герметизовані клапанами. На даному етапі засіб проходить передреєстраційні доклінічні випробування.

Дослідження стабільності трьох досліднопромислових серій (№ 010217, № 010317 та № 010417) аерозольного препарату “Йодозол” виробництва ТОВ “ДЕВІЕ” проводили через 6, 12, 24, 30 місяців зберігання. Контролем служив щойно виготовлений препарат.

Для стандартизації та контролю якості комплексних антибактеріальних препаратів, а також вивчення стабільності при зберіганні були використані методи оцінки лікарського засобу щодо аерозолів, які включають визначення зовнішнього вигляду, перевірку упаковки на герметичність, відсоток виходу вмісту 3 упаковки, ідентичності та вміст діючих речовин, а також мікробіологічну чистоту.

Методи контролю:

- зовнішній вигляд і колір визначали візуально. “Йодозол” повинен являти собою емульсію світложовтого кольору, що утворює при евакуації з балона піну світло-жовтого кольору;

- перевірку на герметичність здійснювали зануренням упаковки в водяну баню. Не повинно бути виділення бульбашок газу;

- вихід вмісту упаковки перевіряли ваговим методом. Вихід вмісту повинен бути не менше 90\% неттомаси;

- обсяг і стабільність піни перевіряли за допомогою мірного циліндра і секундоміра, заміряючи обсяг піни, що утворилася після евакуації препарату в циліндр, і засікаючи час її стабільності. Після видалення вмісту з балона має утворюватися не менше $300,0 \mathrm{~cm}^{3}$ піни, стабільність якої повинна бути не менше 30 хвилин; середню масу однієї дози перевіряли ваговим методом. Середня маса однієї дози повинна складати 50 г. Відхилення в масі не має перевищувати $\pm 10 \%$;

- ідентифікацію та визначення масової частки діючих речовин проведено методами аналітичної хімії, за допомогою специфічних якісних реакцій та титрування. Так, йод ідентифіковано у реакції з крохмалем, а калію йодид - у специфічній реакції з розчином кобальтонітриту та хлороформу при наявності розведеної оцтової кислоти. Кількісне визначення вмісту йоду проведено титруванням розчину препарату 0,1 моль/л розчином натрію тіосульфату з подальшим перераху- 
нком за співвідношенням витраченого титранту до йоду. Кількісне визначення вмісту йодиду калію виконано після відтитровування йоду - шляхом титрування $0,1 \%$ розчином нітрату срібла за наявності розведеної оцтової кислоти та $0,1 \%$ розчину натрію еозинату з перерахунком за співвідношенням витраченого титранту до йодиду калію (Kuleshova et al., 1989; Derzhavna Farmakopeia Ukrainy, 2004).

Вивчення мікробіологічної чистоти проводили прямим посівом згідно з методикою ДФУ (Derzhavna Farmakopeia Ukrainy, 2004; Derzhavna Farmakopeia Ukrainy, 2018).

Випробовування пінистого розчину на мікробіологічну чистоту включав кількісне визначення життєздатних бактерій та грибів, а також виявлення певних видів мікроорганізмів, наявність яких не допускається в нестерильних лікарських засобах. При засіві на живильні середовища використовували такі розведення препарату: середовище № $1-1: 10$, середовище № 2 1:10, середовище № 3 - 1:10, середовище № 8 - 1:20. Для цього 1,0 г препарату збовтували з 10 мл фосфатного буферу (pH 7,0). 1 мл одержаного розчину препарту засівали на рідке та тверде середовище Сабуро, м'ясопептонний бульйон, який містить $2 \%$ глюкози, тіоглікольове середовище та кров'яний агар. Всі середовища із засівом інкубували при температурі 30 $35^{\circ} \mathrm{C}$. Щодня, а також після закінчення терміну інкубації засіви розглядали у розсіяному світлі. Як контроль використовували живильні середовища без додавання препарату. Додатково були проведені дослідження на наявність у розчині бактерій Escherichia coli, Staphylococcus aureus, Pseudomonas aeruginosa (Derzhavna Farmakopeia Ukrainy, 2018).
За показниками якості пінні аерозолі повинні відповідати характеристикам i нормам, зазначеним у таблиці 1.

\section{Таблиця 1}

Показники контролю якості

\begin{tabular}{lc}
\hline \multicolumn{1}{c}{ Найменування показника } & Характеристики та норми \\
\hline 1. Опис & піна світло-жовтого кольору \\
2. Середня маса дози & 50 г $\pm 10,0 \%$ \\
3. рН & $5,0-7,0$ \\
4. Об'єм піни & $300 \mathrm{~cm}^{3} \pm 10,0 \%$ \\
5. Стабільність піни (не & \\
менше), хв & 30 хв (не менше) \\
6. Вихід вмістимого із & \\
упаковки & $90 \%$ (не менше) \\
7. Ідентичність йоду & Позитивна \\
8. Вміст йоду & 5 мг/мл $\pm 10,0 \%$ \\
9. Ідентичність калію йодиду & Позитивна \\
10. Вміст калію йодиду & 10 мг/мл $\pm 10 \%$ \\
11. Стерильність & Повинен бути стерильним \\
\hline
\end{tabular}

\section{Результати та їх обговорення}

Термін придатності встановлювали відповідно до результатів досліджень стабільності в умовах довготривалого зберігання препаратів при діапазоні температур від $+5 \pm 2{ }^{\circ} \mathrm{C}$ до $+25 \pm 2{ }^{\circ} \mathrm{C}$ у захищеному від світла місці через $6,12,24$ та 30 місяців.

Результати стабільності показників в умовах довготривалого дослідження при різних температурних режимах зберігання наведені у таблицях 2-4.

Таблиця 2

Показники якості “Йодозол” в умовах зберігання при температурі $+5 \pm 2{ }^{\circ} \mathrm{C}, \mathrm{M} \pm \mathrm{m}, \mathrm{n}=3$

\begin{tabular}{|c|c|c|c|c|c|}
\hline \multirow{2}{*}{ Показники } & \multicolumn{5}{|c|}{ Термін зберігання (місяців) } \\
\hline & Вихідна & 6 & 12 & 24 & 30 \\
\hline Зовнішній вигляд, колір & \multicolumn{4}{|c|}{$\begin{array}{c}\text { При випуску із балона утворюється піна світло-жовтого } \\
\text { кольору }\end{array}$} & $\begin{array}{c}\text { Випуск із балона переривчас- } \\
\text { тий: піна жовтого кольору }\end{array}$ \\
\hline Герметичність упаковки & \multicolumn{5}{|c|}{ герметична } \\
\hline $\begin{array}{l}\text { Вихід вмісту з упаковки, \% } \\
\text { Об’єм піни } \\
\text { Стабільність піни, хв }\end{array}$ & $94,0 \pm 0,71$ & $92,3 \pm 0,41$ & $93,0 \pm 0,71$ & $\begin{aligned} & 91,7 \pm 0,41^{*} \\
> & 300 \\
> & 30\end{aligned}$ & $90,3 \pm 0,41^{* *}$ \\
\hline Середня маса дози, г, & $54,9 \pm 0,04$ & $54,5 \pm 0,23$ & $54,2 \pm 0,15^{* *}$ & $54,2 \pm 0,04$ & $54,0 \pm 0,07^{* * *}$ \\
\hline Ідентичність йоду & \multicolumn{5}{|c|}{ позитивна } \\
\hline Вміст йоду, мг/мл & $5,3 \pm 0,15$ & $5,1 \pm 0,11$ & $5,0 \pm 0,04$ & $4,9 \pm 0,07$ & $4,6 \pm 0,07^{* *}$ \\
\hline Ідентичність калію йодиду & \multicolumn{5}{|c|}{ позитивна } \\
\hline $\begin{array}{l}\text { Вміст калію йодиду, мг/мл } \\
\text { Мікробна стабільність }\end{array}$ & $10,8 \pm 0,19$ & \multicolumn{4}{|c|}{ відповідає } \\
\hline & \multicolumn{5}{|c|}{ E. coli, P. aeruginosa, S.aureus - відсутні } \\
\hline
\end{tabular}

Примітка: ${ }^{*}-\mathrm{P}<0,05 ;{ }^{* *}-\mathrm{P}<0,01 ;{ }^{* * *}-\mathrm{P}<0,001$

Згідно з отриманими результатами, показники якості дослідних серій препаратів у діапазоні температури від $+5^{\circ} \mathrm{C}$ та $+20^{\circ} \mathrm{C}$, відповідали встановленим нормам впродовж 24 місяців. При підвищенні температури зберігання понад $+25{ }^{\circ} \mathrm{C}$ відбувалося кількісне зниження антимікробних компонентів. Окрім того, при довготривалому зберіганні препаратів випуск вмісту з балона ставало переривистим і піна набувала темно-коричневого відтінку.
3 даних, наведених у табл. 2-4, видно, що мікробіологічна стабільність не змінюється при зберіганні. Значення $\mathrm{pH}$ водних розчинів препарату в процесі всього терміну зберігання суттєво не змінювались. Стабільність аерозолю при тривалому зберіганні визначали також за показником мікробіологічної чистоти. 
Таблиця 3

Показники якості “Йодозол” в умовах зберігання при температурі $+20 \pm 2{ }^{\circ} \mathrm{C}, \mathrm{M} \pm \mathrm{m}, \mathrm{n}=3$

\begin{tabular}{|c|c|c|c|c|c|}
\hline \multirow{2}{*}{ Показники } & \multicolumn{5}{|c|}{ Термін зберігання (місяців) } \\
\hline & Вихідна & 6 & 12 & 24 & 30 \\
\hline Зовнішній вигляд, колір & \multicolumn{4}{|c|}{$\begin{array}{c}\text { При випуску із балона утворюється піна світло-жовтого } \\
\text { кольору }\end{array}$} & $\begin{array}{c}\text { Випуск із балона переривчас- } \\
\text { тий: піна жовтого кольору }\end{array}$ \\
\hline Герметичність упаковки & \multicolumn{5}{|c|}{ герметична } \\
\hline Вихід вмісту з упаковки, \% & $93,3 \pm 0,41$ & $92,0 \pm 0,71$ & $91,3 \pm 0,41^{*}$ & $91,3 \pm 0,41^{*}$ & $90,3 \pm 0,41^{* *}$ \\
\hline Об’єм піни & \multicolumn{5}{|c|}{$>300$} \\
\hline Стабільність піни, хв & \multicolumn{5}{|c|}{$>30$} \\
\hline Середня маса дози, г & $54,9 \pm 0,41$ & $54,6 \pm 0,35$ & $54,6 \pm 0,07^{* *}$ & $54,3 \pm 0,16^{*}$ & $53,8 \pm 0,07^{* * *}$ \\
\hline Ідентичність йоду & \multicolumn{5}{|c|}{ позитивна } \\
\hline Вміст йоду, мг/мл & $5,2 \pm 0,14$ & $5,1 \pm 0,15$ & $5,0 \pm 0,11$ & $4,8 \pm 0,07$ & $4,7 \pm 0,11^{*}$ \\
\hline Ідентичність калію йодиду & \multicolumn{5}{|c|}{ позитивна } \\
\hline Вміст калію йодиду, мг/мл & $10,7 \pm 0,2$ & $10,6 \pm 0,29$ & $10,4 \pm 0,27$ & $10,0 \pm 0,08^{*}$ & $9,8 \pm 0,14^{*}$ \\
\hline Мікробна стабільність & \multicolumn{2}{|c|}{ E. coli, P. aeruginosa, S.aureus - відсутні } & & & \\
\hline
\end{tabular}

Таблиця 4

Показники якості “Йодозол” в умовах зберігання при температурі $+25 \pm 2{ }^{\circ} \mathrm{C}, \mathrm{M} \pm \mathrm{m}, \mathrm{n}=3$

\begin{tabular}{|c|c|c|c|c|c|}
\hline \multirow{2}{*}{ Показники } & \multicolumn{5}{|c|}{ Термін зберігання (місяців) } \\
\hline & Вихідна & 6 & 12 & 24 & 30 \\
\hline Зовнішній вигляд, колір & \multicolumn{4}{|c|}{$\begin{array}{l}\text { При випуску із балона утворюється піна світло- } \\
\text { жовтого кольору }\end{array}$} & $\begin{array}{c}\text { Випуск із балона переривчастий: } \\
\text { піна світло-жовтого кольору }\end{array}$ \\
\hline Герметичність упаковки & \multirow{4}{*}{$92,7 \pm 0,41$} & \multirow{4}{*}{$91,7 \pm 0,41$} & \multicolumn{2}{|c|}{ герметична } & \multirow{4}{*}{$90,0 \pm 0,00^{* *}$} \\
\hline Вихід вмісту з упаковки, \% & & & $91,0 \pm 0,00$ & $90,3 \pm 0,41^{*}$ & \\
\hline Об’єм піни & & & & $>300$ & \\
\hline Стабільність піни, хв & & & & $>30$ & \\
\hline Середня маса дози, г & \multirow[t]{2}{*}{$54,8 \pm 0,07$} & \multirow[t]{2}{*}{$54,7 \pm 0,04^{*}$} & $54,6 \pm 0,04^{*}$ & $54,1 \pm 0,12^{* *}$ & \multirow[t]{2}{*}{$54,0 \pm 0,15^{* *}$} \\
\hline Ідентичність йоду & & & & позитивна & \\
\hline Вміст йоду, мг/мл & \multirow[t]{2}{*}{$5,2 \pm 0,12$} & \multirow[t]{2}{*}{$5,1 \pm 0,11$} & $5,0 \pm 0,04$ & $4,9 \pm 0,07$ & \multirow[t]{2}{*}{$4,7 \pm 0,04^{*}$} \\
\hline Ідентичність калію йодиду & & & & позитивна & \\
\hline Вміст калію йодиду, мг/мл & \multirow[t]{2}{*}{$10,7 \pm 0,16$} & \multirow{3}{*}{$10,6 \pm 0,16$} & $10,4 \pm 0,23$ & $10,1 \pm 0,22$ & \multirow{2}{*}{$9,8 \pm 0,12^{* *}$} \\
\hline Мікробна стабільність & & & & відповідає & \\
\hline & \multicolumn{3}{|c|}{ E. coli, P. aeruginosa, S.aureus - відсутні } & & \\
\hline
\end{tabular}

Таким чином, відповідно до результатів дослідження встановлений термін придатності препаратів складав повних два роки при рекомендованій температурі зберігання від +5 до $+20{ }^{\circ} \mathrm{C}$.

\section{Висновки}

Визначено оптимальні терміни зберігання лікарського препарату у металевих контейнерах (балонах) - за температури від +5 до $+20{ }^{\circ} \mathrm{C}$, що відповідає нашим кліматичним умовам. Отримані експериментальні дані свідчать, що граничний термін зберігання препарату “Йодозол” складає 2 роки. За таких умов коливання показників якості, а саме об'єму піни, іiі стабільності, вмісту йоду, калію йодиду та мікробіологічна чистота дослідних зразків препарату перебувала в межах допустимих відхилень. Результати експерименту враховано при розробці нормативної документації на препарат.

Перспективи подальших досліджень. Подальші дослідження будуть черговим етапом передреєстраційних випробувань, спрямованих на проведення клінічних випробувань препарату “Йодозол” на цільових тваринах.

\section{References}

Kotsyumbas, I.Ya., Malik, O.G., \& Patereha I.P. et al. (2006). Doklinichni doslidzhennja veterinarnih likars'kih zasobiv. Lviv: Triad plus (in Ukrainian).

Heorhiievskyi, V., Liapunov, M., \& Bezuhla, O. (2004). Nastanova 42-3.3:2004. Nastanovy z yakosti. Likarski zasoby. Vyprobuvannia stabilnosti. K.: MOZ Ukrainy (in Ukrainian)

Todoriuk, V.B., Hunchak, V.M., Gutyj, B.V., Gufriy, D.F., Hariv, I.I., Khomyk, R.I. , \& Vasiv, R.O. (2018). Preclinical research of the experimental preparation "Ferosel T". Ukrainian Journal of Veterinary and Agricultural Sciences, 1(1), 3-9. doi: 10.32718/ujvas1-1.01.

Gutyj, B., Paska, M., Levkivska, N., Pelenyo, R., Nazaruk, N., \& Guta, Z. (2016). Study of acute and chronic toxicity of 'injectable mevesel' investigational drug. Biological Bulletin of Bogdan Chmelnitskiy Melitopol State Pedagogical University, 6(2), 174180. doi: $10.15421 / 201649$.

Gutyj, B., Grymak, Y., Hunchak, V., Mysak, A., Nazaruk, N., Brezvyn, O., Hariv, I., Shcherbatyy, A., Semeniv, B., Bushueva, I., Parchenko, V., \& Kaplaushenko, A. (2018). Preclinical searches of the preparation 
Thireomagnile. Ukrainian Journal of Ecology, 8(1), 688-695. doi: 10.15421/2018 267.

Kuleshova, M.I., Guseva, L.N., \& Sivitskaya, O.K. (1989). Analiz lekarstvennykh form izgotavlevayemykh $\mathrm{v}$ aptekakh. M.: Meditsina (in Russian).
Derzhavna Farmakopeia Ukrainy (2004). Derzh. p-vo "Naukovo-ekspertnyi farmakopeinyi tsentr". 1-e vyd., Dopovnennia 1. Kharkiv: RIREH (in Ukrainian).

Derzhavna Farmakopeia Ukrainy (2018). Derzh. p-vo "Naukovo-ekspertnyi farmakopeinyi tsentr". 2-e vyd., Dopovnennia 2. Kharkiv. http://moz.gov.ua/ uploads/0/4029-dn_20180314_476_dod.pdf (in Ukrainian). 